\title{
Immunohistological analysis of lung tissue from patients with cryptogenic fibrosing alveolitis suggesting local expression of immune hypersensitivity
}

\author{
DA CAMPBELL, LW POULTER, G JANOSSY, RM DU BOIS
}

From the Departments of Immunology and Thoracic Medicine, Royal Free Hospital School of Medicine, London

ABSTRACT Immunohistological analysis using monoclonal antibodies in conjunction with histochemical techniques has been applied to lung biopsy material from patients with cryptogenic fibrosing alveolitis. Subsets of lymphoid and non-lymphoid cells have been identified in situ. This analysis showed that the inflammatory cells present were predominantly mononuclear. Most of the lymphoid cells were B lymphocytes, organised into follicles with occasional germinal centre formation. IgM was the major class of immunoglobulin expressed. Both $\mathrm{T}^{+}$and $\mathrm{T}^{+}$lymphocytes were seen diffusely distributed in the interstitium. The $\mathrm{T}^{+}$positive cells were also seen within the B lymphoid follicles. Almost all non-lymphoid cells expressed the phenotype of inflammatory macrophages, but a few also expressed a phenotype characteristic of interdigitating cells. These results suggest that a local B lymphoid immune response is occurring in cryptogenic fibrosing alveolitis. The possibility that a cell mediated immune response is also emerging is discussed.

Current ideas about the pathogenesis of cryptogenic fibrosing alveolitis owe much to the introduction of bronchoalveolar lavage as a diagnostic and investigative tool in pulmonary medicine (for reviews see refs 1-4) and to studies of animal models of pulmonary fibrosis. ${ }^{5}$ Although the aetiology is unknown it is generally accepted that chronic alveolar inflammation is the forerunner of the irreversible interstitial fibrosis characteristic of cryptogenic fibrosing alveolitis $^{26}$ and that the immune system is implicated in the development of this chronic alveolitis. ${ }^{78}$

It is argued that in response to an unknown antigenic stimulus macrophages and $T$ lymphocytes are activated, B lymphocytes proliferate, and plasma cells produce immunoglobulins. ${ }^{2}$ This results in immune complex formation and deposition along with complement in the pulmonary parenchyma. ${ }^{89}$ The immune complexes activate macrophages to

Address for reprint requests: Dr DA Campbell, Department of Thoracic Medicine, Royal Free Hospital, London NW3 2QG.

Accepted 28 January 1985 release chemotactic factors causing neutrophil accumulation, and also fibronectin and alveolar macrophage derived growth factor, which stimulate fibroblast proliferation, ultimately leading to the deposition of excessive interstitial collagen. ${ }^{10}$ Lymphocytes are present in the inflammatory cell infiltrate in cryptogenic fibrosing alveolitis, and in previous histopathological studies lymphoid follicles have been found within the pulmonary parenchyma in some cases." The question of whether the tissue reaction is induced locally or reflects a systemic disorder has yet to be resolved.

The advent of monoclonal antibodies (Mc Ab-s) as "markers" of cell subpopulations has made possible the discrete analysis of complex tissue reactions, ${ }^{12}$ which to some extent can be related to the divergent functions of morphologically similar cells. ${ }^{13}$ We studied lung tissue from patients with cryptogenic fibrosing alveolitis using these techniques, to determine whether there was any histological evidence for the local induction and recall of an immune response in this condition. 


\section{Methods}

\section{PATIENTS}

Six patients underwent open lung biopsy to confirm a clinically suspected diagnosis of cryptogenic fibrosing alveolitis.

In none of the cases was there clinical or laboratory evidence to implicate a known cause of fibrosing alveolitis. There was no history of drug use known to be associated with pulmonary fibrosis, or of exposure to organic or inorganic dust. None of the patients were in contact with allergens known to cause extrinsic allergic alveolitis. All were negative for avian and Aspergillus precipitins. Details of the patients are summarised in table 1.

\section{COLLECTION OF TISSUE AND SECTIONS}

At thoracotomy biopsy samples (about $15 \mathrm{~cm}^{3}$ ) were removed. Control tissue samples were taken from unaffected areas of carcinomatous lung removed at pneumonectomy (two cases).

In all cases the biopsy samples were cut into two pieces. One large piece was fixed in calcium formalin and processed for routine histopathological study, while the other piece $\left(0.5-1 \mathrm{~cm}^{3}\right)$ was coated with OCT and frozen in isopentane cooled in a bath of liquid nitrogen.

Sections of $6 \mu \mathrm{m}$ were cut from these frozen blocks on a cryostat maintained at $-25^{\circ} \mathrm{C}$. Sections were air dried for one hour, fixed for five minutes in chloroform and acetone $(1: 1)$ and stored at $-20^{\circ} \mathrm{C}$ until use.

IMMUNOLOGICAL ANALYSIS

The panel of monoclonal antibodies used to detect specific cell populations is given in table 2. In some cases combinations of reagents or combinations of antibodies and cytochemical reactions were used. ${ }^{314}$ Where single reagents were used immunocytochemical methods were used to visualise the cell populations. ${ }^{15}$ Where combinations of two monoclonal antibodies were added to the sections, immunofluorescence techniques using immunoglobulin class specific second layers conjugated to fluorescein isothiocyanate and tetraethyl rhodamine isothiocyanate were used to distinguish the two cell populations stained. ${ }^{12}$

Histochemistry A standard method to detect acid phosphatase activity was used, ${ }^{16}$ either alone or in combination with immunofluorescence staining with a monoclonal antibody. ${ }^{12}$

Identification of cell subpopulations Specific subpopulations of both lymphoid and non-lymphoid cells were identified by their phenotype, as previously determined on normal tissues in which morphology and tissue distributions could be used to confirm identity. ${ }^{17} 18$ All studies were performed in duplicate and repeated on sections taken at varying depths within the biopsy samples.

\section{Results}

\section{HISTOPATHOLOGY}

Fibrosis was seen in all six specimens. In five cases cellular infiltration of the interstitium was variable and in the remaining case there was minimal evidence of cellular infiltration. Where cellular accumulation was evident many mononuclear cells were present, including both lymphocytes and mac-

Table 1 Details of the patients

\begin{tabular}{|c|c|c|c|c|c|c|c|c|c|c|}
\hline \multirow{2}{*}{$\begin{array}{l}\text { Age } \\
(y)\end{array}$} & \multirow[t]{2}{*}{ Sex } & \multirow{2}{*}{$\begin{array}{l}\text { Cigarettes/ } \\
\text { day }\end{array}$} & \multirow[t]{2}{*}{ Diagnosis } & \multicolumn{2}{|c|}{ Clinical features } & \multicolumn{5}{|c|}{ Diagnostic tests } \\
\hline & & & & Crackles & Clubbing & $\begin{array}{l}\text { Immuno- } \\
\text { globulins }\end{array}$ & Rh factor & $A N F$ & $\begin{array}{l}\text { Circulating } \\
\text { immune } \\
\text { complexes }\end{array}$ & Lung function \\
\hline 70 & $\mathbf{M}$ & 0 & CFA & + & + & $\begin{array}{l}\text { Raised IgG } \\
\text { and } \operatorname{IgA}\end{array}$ & - & $\begin{array}{l}\text { Not } \\
\text { available }\end{array}$ & - & $\begin{array}{l}\text { Restrictive ventilatory } \\
\text { defect, reduced Kco }\end{array}$ \\
\hline 56 & $\mathbf{F}$ & 0 & $\begin{array}{l}\text { CFA and } \\
\text { Sjögren's } \\
\text { syndrome }\end{array}$ & + & + & Normal & - & - & $+(\operatorname{IgG})$ & $\begin{array}{l}\text { Restrictive ventilatory } \\
\text { defect, normal Kco }\end{array}$ \\
\hline 59 & $\mathbf{F}$ & 0 & CFA & - & - & Normal & - & - & $\begin{array}{l}\text { Not } \\
\text { available }\end{array}$ & $\begin{array}{l}\text { Normal lung volumes } \\
\text { reduced K co }\end{array}$ \\
\hline 50 & F & 0 & CFA & + & + & Raised IgG & $\begin{array}{l}+ \\
(1: 10 \\
240)\end{array}$ & - & $+(\operatorname{IgM})$ & $\begin{array}{l}\text { Restrictive ventilatory } \\
\text { defect, reduced Kco }\end{array}$ \\
\hline 44 & $\mathbf{M}$ & 40 & CFA & - & + & Normal & - & $+(1: 10)$ & $\begin{array}{l}\text { Not } \\
\text { available }\end{array}$ & $\begin{array}{l}\text { Mixed restrictive and } \\
\text { obstructive ventilatory } \\
\text { defect, reduced Kco }\end{array}$ \\
\hline 61 & $\mathbf{M}$ & 20 & CFA & + & - & Raised IgA & - & - & $\begin{array}{l}\text { Not } \\
\text { available }\end{array}$ & $\begin{array}{l}\text { Normal lung volumes, } \\
\text { reduced Kco }\end{array}$ \\
\hline
\end{tabular}

CFA-cryptogenic fibrosing alveolitis; ANF-antinuclear factor; Kco-transfer coefficient (gas transfer). + indicates positive and - negative. 
Table 2 Antibodies used in this study

\begin{tabular}{|c|c|c|c|}
\hline Designation & Type & Source & Specificity \\
\hline $\begin{array}{l}\text { RFDR1 } \\
\text { RFD1 } \\
\text { RFD2 } \\
\text { RFT1 } \\
\text { OKT4 } \\
\text { RFT8 } \\
\text { RFB4 } \\
\text { BA1 } \\
\text { RFD3 } \\
\text { RFM1 } \\
\text { Leu M2 } \\
\text { Anti-IgM }\end{array}$ & $\begin{array}{l}\text { Mouse antihuman } \\
\text { monoclonal antibody }\end{array}$ & $\begin{array}{l}\text { RFH } \\
\text { RFH } \\
\text { RFH } \\
\text { RFH } \\
\text { Ortho Pharmaceuticals Co } \\
\text { RFH } \\
\text { RFH } \\
\text { Hybritech } \\
\text { RFH } \\
\text { RFH } \\
\text { Beckton-Dickinson } \\
\text { Sigma }\end{array}$ & $\begin{array}{l}\text { Class II MHC antigens } \\
\text { Interdigitating cells and subpopulation of B cells } \\
\text { Monocytes and macrophages, some granulocytes and T cells } \\
\text { Pan T cell/small population of B lymphocytes; B-CLL } \\
\text { Helper/inducer type T cells } \\
\text { Suppressor/cytotoxic type T cells } \\
\text { Pan-B cells } \\
\text { Mantle zone B cells } \\
\text { Dendritic reticulum cells } \\
\text { Granulocytes } \\
\text { Monocytes and macrophages } \\
\text { IgM }\end{array}$ \\
\hline Anti-IgG & Goat antihuman & Sigma & IgG \\
\hline Anti-IgA & heterologous serum & Sigma & $\operatorname{Ig} A$ \\
\hline Anti-IgD & & Kallestad & IgD \\
\hline
\end{tabular}

RFH-Royal Free Hospital, Department of Immunology

rophage like cells, the latter being in the majority. Macrophage like cells were also seen within the alveolar spaces. In five of the six patients studied clearly defined lymphoid follicles could be seen. Infiltration by polymorphonuclear leucocytes was variable in two samples, and was not an obvious feature in the other four cases examined. The control samples of lung showed normal histological appearances.

\section{IMMUNOHISTOLOGY \\ Lymphocytes}

The distribution and phenotype of lymphoid cells are summarised in table 3. Most of the lymphoid cells present showed positive staining with monoclonal antibody RFB4 and expressed surface IgM, indicating that they were $\mathrm{B}$ lymphocytes. $\mathrm{B}^{+}, \mathrm{IgM}^{+}$ cells made up almost all the cells in the follicles (fig, $a$ ). Most of these cells $(>80 \%)$ were also BA $1^{+}$ and expressed IgD. The pattern of staining in many of these $\mathrm{B}$ cell follicles showed a corona of $\mathrm{BA} 1^{+}$, $\mathrm{IgD}^{+}$cells around an area of $\mathrm{BA}^{-}{ }^{-}, \mathrm{IgD}^{-}$cells. In other tissue areas $\mathrm{BA}^{+}{ }^{+} \mathrm{IgD}^{+}$cells were seen throughout the lymphoid aggregates. Some of these aggregates were very small, suggesting that the follicles were cut through peripheral rather than central areas. In the larger follicles deposits of $\mathrm{IgM}$ and IgG were seen (fig), either as lacy complexes in intercellular areas or on lymphocytes. These immunoglobulin deposits were detected around the dendritic reticulum cells (see below). B4 ${ }^{+}$cells were also found distributed diffusely throughout the rest of the interstitium.

Staining with RFT1 revealed a significant but minor population of $\mathrm{T}$ lymphocytes. Analysis with reagent combination RFT1/IgM showed that no $\mathrm{T}^{+}$ cells expressed surface IgM; they are therefore $T$ lymphocytes and not immature B lymphocytes (compare $a$ and $b$ in the figure). The further characterisation of $T$ cells showed that cells of the helper $\left(\mathrm{T}^{+}\right)$and suppressor-cytotoxic $\left(\mathrm{T}^{+}\right)$phenotypes were present in a ratio of about $2: 1$. Some $T$ cells were seen scattered within B cell follicles (fig, $b$ ). These cells were almost exclusively $\mathrm{T}^{+}$.

Immunoglobulin class analysis showed surface IgM on most $\mathrm{B}^{+}$cells in follicles. Most plasma cells

Table 3 Distribution of lymphoid cells in lung biopsy samples from patients with cryptogenic fibrosing alveolitis

\begin{tabular}{|c|c|c|c|}
\hline Cell & Phenotype & $\begin{array}{l}\text { \% of total } \\
\text { lymphocytes* }\end{array}$ & Distribution \\
\hline $\begin{array}{l}\text { Within the lymphoid follicle } \\
\text { B lymphocytes } \\
\text { B lymphocytes }\end{array}$ & $\begin{array}{l}\mathrm{RFB4}^{+}, \mathrm{IgM}^{+}, \mathrm{IgD}^{+}, \mathrm{BA}^{+}, \mathrm{RFT}^{-} \\
\mathrm{RFB4}^{+}, \mathrm{IgM}^{+}, \mathrm{IgD}^{-}, \mathrm{BA}^{-}, \mathrm{RFT}^{-}\end{array}$ & $\begin{array}{l}40-50 \\
20-30\end{array}$ & $\begin{array}{l}\text { Mantle zone } \\
\text { Germinal centre }\end{array}$ \\
\hline $\begin{array}{l}\text { Diffusely distributed lymphoid ce } \\
\text { B lymphocytes } \\
\text { T lymphocytes (helper type) }\end{array}$ & $\begin{array}{l}\text { Rls } \\
\mathrm{RFB}_{4}^{+}, \mathrm{IgM}^{+}, \mathrm{IgDD}^{+}, \mathrm{BA}_{1}^{+}, \mathrm{RFT}^{-} \\
\mathrm{RFT}^{-}{ }^{+}, \mathrm{OKT}_{4}^{+}, \mathrm{RFT}^{-}\end{array}$ & $\begin{array}{r}<10 \\
20\end{array}$ & \multirow{2}{*}{$\begin{array}{l}\text { In interstitium } \\
\text { In the interstitium and a few scattered within } \\
\mathrm{B} \text { cell follicles; absent in the airspaces } \\
\text { In the interstitium; absent in germinal centres } \\
\text { and airspaces }\end{array}$} \\
\hline $\begin{array}{l}\text { T lymphocytes } \\
\text { (suppressor/cytotoxic type) }\end{array}$ & $\mathrm{RFT}_{1}{ }^{+}, \mathrm{OKT}_{4}^{-}, \mathrm{OKT}^{+}$ & 10 & \\
\hline
\end{tabular}

\footnotetext{
${ }^{*}$ Visual subjective assessment.
} 



( $a$ and $b$ ) Distribution of $T$ and $B$ lymphocytes in the lung biopsy sample from a patient with cryptogenic fibrosing alveolitis. This section was labelled with a combination of antihuman IgM (tetraethyl rhodamine isothiocyanate, red fuorochrome in (a) and RFT1 (ftuorescein isothiocyanate, green fuorochrome in (b). The same area was photographed with selective filters. In (a) IgM ${ }^{+} B$ lymphocytes form a secondary follicle within the lung interstitium. Within the follicle a germinal centre with IgM deposits is seen (enclosed by circles). On the mantle B cells express membrane IgM (enclosed by diamonds). Other IgM ${ }^{+} B$ cells are scattered diffusely in the interstitium. In (b) RFT1 ${ }^{+}$T lymphocytes are scattered throughout the interstitium (open arrow) and also appear within the germinal centre (closed arrows). These latter $T$ cells were exclusively $\mathrm{T4}^{+}$(see results).

$(c$ and $d)$ Distribution of macrophages in the lung biopsy sample from a patient with cryptogenic fibrosing alveolitis. The section was labelled with a combination of anti-HLA-DR antibody, with the use of indirect immunoftuorescence $(R F D R 1$ in $(c), \times 210)$ and cytochemical staining for acid phosphatase (Hohler illumination in $(d), \times 335)$. Almost all macrophages are $H L A-D R^{+}, A C P^{+}$. Typical examples are arrowed. 
contained cytoplasmic IgM (about $70 \%$ ), while the rest contained IgG (about $30 \%$ ). No $\operatorname{IgA}{ }^{+} \mathrm{B}$ cells or any IgA containing plasma cells were seen.

In the air spaces no B cells or T cells were seen.

\section{Non-lymphoid cells}

The distribution and phenotype of macrophage like cells are summarised in table 4. Large round or dendritic shaped non-lymphoid mononuclear cells constituted the major inflammatory cell type present in the tissues. Appreciable numbers of these cells were also seen in the air spaces. The vast majority of these cells $(>90 \%)$ expressed the phenotype of inflammatory macrophages (table 4 and fig, $c, d$ ). A few cells expressing the phenotype of interdigitating cells were present within the interstitium, and in some cases within the air spaces.

Within the lymphoid follicles dendritic reticulum cells were identified. This is consistent with the concept that the essential cellular elements of germinal centres are present within the lung interstitium in cryptogenic fibrosing alveolitis.

\section{Expression of class II MHC antigens}

Over $90 \%$ of the macrophage like cells in the cryptogenic fibrosing alveolitis lung biopsy samples expressed HLA-DR (fig, $c$ ). Even the macrophages seen in the air spaces were HLA-DR ${ }^{+}$. DR expression was also seen on the B lymphocytes in the follicles.

Of further interest was the observation that in one case the epithelium lining the air spaces and terminal respiratory ducts was also HLA-DR ${ }^{+}$. This was not the case in control tissues.

Combination staining with monoclonal antibody RFDR1 and ACP showed that over $90 \%$ of the HLA-DR ${ }^{+}$macrophage like cells were $\mathrm{ACP}^{+}$(fig, d) (also see above).

\section{Discussion}

There is little doubt that immune mechanisms are implicated in the pathogenesis of cryptogenic fibrosing alveolitis. ${ }^{2710}$ The disease can be associated with hypergammaglobulinaemia, circulating autoantibodies, and immune complexes. ${ }^{8}$ Raised immunoglobulin levels and immune complexes are found in bronchoalveolar lavage fluid, ${ }^{19}$ and the pulmonary parenchymal deposition of immunoglobulins and complement components indicates immune complex deposition at sites of disease activity. It has been suggested that immunoglobulin is produced locally within the lung tissue. ${ }^{20}$ The source of the antigenic stimulus is unknown, although type I collagen has been implicated. ${ }^{2}$ As well as a humoral immune response, the activation of a cell mediated response has been demonstrated, albeit systemically ${ }^{21}$; and a transient cellular sensitivity to homologous type I collagen has been shown in an animal model using bleomycin to induce pulmonary fibrosis. ${ }^{22}$

In the immunological studies described here the most striking feature observed was the formation of B lymphocyte follicles. This work confirms previous observations $^{611}$ and further characterises the cellular elements of these follicles, demonstrating the presence of true germinal centres. These B cell nodules contain not only dendritic reticulum cells ${ }^{23}$ and a selected $\mathrm{T}^{+}$lymphocyte subset but in at least a proportion of cases also larger $\mathrm{BA}^{-}, \mathrm{IgD}^{-}$cells in the central area. This phenotypic feature is typical of centroblasts. ${ }^{23}$ These cells are surrounded by lacy Ig deposits on dendritic cells. Thus, although the size of these follicles is small, they are developing into secondary follicles with germinal centre formation. ${ }^{23}$ The presence of dendritic reticulum cells in these follicles suggests that local antigen trapping and presentation to B lymphocytes is occurring. Germinal centre formation is further evidence for the local induction of an immune response, and the generation of B lymphocyte memory cells is its principle sequela ${ }^{24}$ Most of the plasma cells seen (cytoplasmic localisation of immunoglobulin) were producing IgM and others were producing IgG. These observations, and the work of others who have observed that immune complexes in which these two classes of antibody are present are found in this disease, are consistent with the occurrence of local antibody responses within the lung tissue. ${ }^{127}$

Table 4 Macrophage like cells in lung biopsy samples from patients with cryptogenic fibrosing alveolitis

\begin{tabular}{|c|c|c|c|}
\hline Cell & Phenotype* & $\begin{array}{l}\text { \% of total } \\
\text { macrophage like cells } \dagger\end{array}$ & Distribution \\
\hline Dendritic reticulum cells & $\begin{array}{l}\mathrm{RFD}^{+}{ }^{+}, \mathrm{RFDR}^{-}{ }^{-}, \mathrm{Leu} \mathrm{M}^{-}{ }^{-} \\
\mathrm{RFD}^{-}\end{array}$ & $<5$ & Restricted to the centre of follicles \\
\hline Macrophages & $\begin{array}{l}\mathrm{RFD}^{-}, \mathrm{RFDR}^{+}{ }^{+}, \mathrm{Leu} \mathrm{M}^{+}{ }^{+}, \\
\mathrm{RFD}_{2}{ }^{+}, \mathrm{ACP}^{+}, \mathrm{RFD}^{-}\end{array}$ & 90 & $\begin{array}{l}\text { Widely distributed in large numbers both in } \\
\text { the interstitium and in the air spaces }\end{array}$ \\
\hline Interdigitating cells & 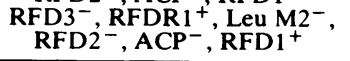 & $<10$ & $\begin{array}{l}\text { Sparsely distributed in the interstitium; in } \\
\text { the air spaces }\end{array}$ \\
\hline
\end{tabular}

* Determined by staining in consecutive sections and reference to previous studies.

† Visual subjective assessment. 
An important step in the induction of responsiveness to all protein antigens is the activation of helper $T$ cells. This is induced not by free antigens but only by antigen presented by an accessory cell bearing HLA-DR Ag. ${ }^{25}$ The regulation of expression of HLA-DR Ag on macrophages may well be critical to its role in the induction of immune responsiveness. ${ }^{26}$ Inflammatory macrophages were the principal non-lymphoid cell present in the interstitium and air spaces in the lung biopsy samples we examined. This result is in agreement with the identification of similar cells in bronchoalveolar lavage fluid. ${ }^{27}$ In the cases studied almost all macrophages expressed class II MHC (HLA-DR) molecules. This reflects the findings from studies on alveolar macrophages isolated from bronchoalveolar lavage fluid not only in cryptogenic fibrosing alveolitis but also in sarcoidosis, ${ }^{28}$ a condition thought to be associated with a cell mediated immune response..$^{29}{ }^{30}$ Non-immune cells may also express HLA-DR and the observation that type II alveolar epithelial cells expressed this antigen in one of the cases studied is of great interest. It reflects the circumstances described in certain dermatoses in which the presence of these molecules is associated with cell mediated reactions. ${ }^{31}$

The role of $T$ cell subpopulations in cryptogenic fibrosing alveolitis remains ill defined, with the possible exception of the helper role of the $\mathrm{T}^{+}$cells within the lymphoid follicles. This distinguishes cryptogenic fibrosing alveolitis from other chronic inflammatory conditions, such as sarcoidosis, and the pathological process occurring in rheumatoid synovium, where $T$ cells appear to play a major part in the inflammatory response. ${ }^{29}{ }^{32}$ Finally, the presence of small numbers of interdigitating cells (possible $\mathrm{T}$ lymphocyte inducers) might reflect the systemic $T$ cell activation already reported to occur in this condition. ${ }^{21}$

Our study provides evidence for the local induction and recall of a B cell humoral immune response in cryptogenic fibrosing alveolitis. Possibly both humoral antibody and cell mediated immune mechanisms are operative. Attempts to establish the role of each in the pathogenesis of this condition will await correlation of the results of immunohistological phenotypic analysis with those of in vitro functional analysis, perhaps with the use of bronchoalveolar lavage fluid to obtain immune effector cells. Although bronchoalveolar lavage can retrieve large numbers of inflammatory and immunocompetent cells, there is so far no firm evidence that the results reflect the pattern of cellular infiltration in the interstitium. Further studies are underway which will attempt to address that question by comparing the surface antigen expression of cells in bronchoalveolar lavage with those in lung tissue.
This work was supported by a grant from the Nuffield Foundation. DAC is a visiting clinical research fellow supported by a grant to RM duB from the North East Thames Regional Health Authority.

\section{References}

1 Crystal RG, Gadek JE, Ferrans VJ, Fulmer JD, Line $\mathrm{BR}$, Hunninghake GW. Interstitial lung disease: current concepts of pathogenesis, staging and therapy. $\mathrm{Am}$ $J$ Med 1981;70:542-68.

2 Crystal RG, Bitterman PB, Rennard SI, Hance AJ, Keogh BA. Interstitial lung diseases of unknown cause. Disorders characterized by chronic inflammation of the lower respiratory tract. $N$ Engl J Med 1984;310:15466.

3 Turner-Warwick M. Interstitial pneumonias and fibrosing alveolitis. In: Turner-Warwick M, ed. Immunology of the lung. London: Edward Arnold, 1978:216-48.

4 Gee JBL, Fick RB. Bronchoalveolar lavage. Thorax 1980;35: 1-8.

5 Thrall RS, Barton RW. A comparison of lymphocyte populations in lung tissue and in bronchoalveolar lavage fluid of rats at various times during the development of bleomycin-induced pulmonary fibrosis. Am Rev Respir Dis 1984;129:279-83.

6 Rudd RM, Haslam PL, Turner-Warwick M. Cryptogenic fibrosing alveolitis: relationships of pulmonary physiology and bronchoalveolar lavage to response to treatment and prognosis. Am Rev Respir Dis 1981;124: 1-8.

7 Reynolds HY. Immunologic lung diseases (part 2). Chest 1982;81:745-51.

8 Dreisin RB. Lung diseases associated with immune complexes. Am Rev Respir Dis 1981;124:738-55.

9 Dreisin RB, Schwarz ML, Theofilopoulos MD, Stanford RE. Circulating immune complexes in the idiopathic interstitial pneumonias. $N$ Engl J Med 1979;298:353-7.

10 Snider GL. Interstitial pulmonary fibrosis. Which cell is the culprit? Am Rev Respir Dis 1983;127:535-9.

11 Turner-Warwick M, Burrows B, Johnson A. Cryptogenic fibrosing alveolitis: Clinical features and their influence on survival. Thorax 1980;35:171-80.

12 Poulter LW, Chilosi M, Seymour GJ, Hobbs S, Janossy G. Immunofluorescence membrane staining and cytochemistry applied in combination for analysing cell interactions in situ. In: Polak JM, Van Noorden S, eds. Immunocytochemistry today: practical applications and biology. Bristol: John Wright, 1983:233-48.

13 Poulter LW. Antigen presenting cells in situ. Their identification and involvement in immunopathology. Clin Exp Immunol 1983;53:513-20.

14 Poulter LW, Duke O, Hobbs S, Janossy G, Panayi GS, Seymour GJ. The involvement of interdigitating (antigen presenting) cells in the pathogenesis of rheumatoid arthritis. Clin Exp Immunol 1983;51:247-54.

15 Mason DY, Abdulaziz Z, Falini B, Stein H. Double immunoenzymatic labelling. In: Polak JM, Van Noorden S, eds. Immunocytochemistry today: practical applications and biology. Bristol: John Wright, 1983:113-28. 
16 Loyda Z, Gossrav R, Schiebler TH. Enzyme histochemistry. Berlin: Springer-Verlag, 1979:71-87.

17 Poulter LW, Seymour GJ, Duke O, Janossy G, Panayi GS. Immunohistological analysis of delayed-type hypersensitivity in man. Cell Immunol 1982;74:35869.

18 Poulter LW, Collings LA, Tung KS, Waters MFR. Parasitism of antigen presenting cells in hyperbacillary leprosy. Clin Exp Immunol 1984;55:611-7.

19 Hunninghake GW, Gadek JE, Lawley TJ, Crystal RG. Mechanisms of neutrophil accumulation in the lungs of patients with ideopathic pulmonary fibrosis. J Clin Invest 1981;68:259-68.

20 Lawrence EC, Martin RR, Blaese RM, et al. Increased bronchoalveolar IgG secreting cells in interstitial lung diseases. $N$ Engl J Med 1980;302:1186-8.

21 Kravis TC, Ahmed A, Brown TE, Fulmer JD, Crystal RG. Pathogenic mechanisms in pulmonary fibrosis: collagen-induced migration inhibition factor production and cytotoxicity mediated by lymphocytes. J Clin Invest 1976;58:1223-32.

22 Schrier DJ, Phan SH, Ward PA. Cellular sensitivity to collagen in bleomycin-treated rats. J Immunol 1982;129:2156-9.

23 Stein $\mathrm{H}$, Gerdes J, Mason DY. The normal and malignant germinal centre. Clin Haematol 1982;11:531-59.

24 Klaus GGB, Humphrey JH, Kunkl A, Dongworth DW. The follicular dendritic cell: its role in antigen presentation in the generation of immunological memory. Immunol Rev 1980;53:3-28.

25 Benacerraf $\mathrm{B}$. Role of $\mathrm{MHC}$ gene products in immune regulation. Science 1981;212:1229-38.

26 Unanue ER, Beller DI, Lu CY, Allen PM. Antigen presentation: comments on its regulation and mechanism. J Immunol 1984;132:1-5.

27 duBois RM, Townsend PJ, Cole PJ. Alveolar macrophage lysosomal enzyme and $\mathrm{C} 3 \mathrm{~b}$ receptors in cryptogenic fibrosing alveolitis. Clin Exp Immunol 1980;40:60-5.

28 Razma AG, Lynch JP, Wilson BS, Ward PA, Kunkel SL. Expression of Ia-like (DR) antigen on human alveolar macrophages isolated by bronchoalveolar lavage. Am Rev Respir Dis 1984;129:419-24.

29 Mishra BB, Poulter LW, Janossy G, James DG. The distribution of lymphoid and macrophage-like cell subsets of sarcoid and kveim granulomata: possible mechanism of negative PPD reaction in sarcoidosis. Clin Exp Immunol 1983;54:705-14.

30 Modlin RL, Hofman RM, Meyer PR, Sharma OP, Taylor CR, Rea TH. In situ demonstration of T lymphocyte subsets in granulomatous inflammation: leprosy, rhinosclerosis and sarcoidosis. Clin Exp Immunol 1983;51:430-8.

31 Lampert IA. Expression of HLA-DR (Ia-like) antigen on epidermal keratinocytes in human dermatoses. Clin Exp Immunol 1984;57:93-100.

32 Duke O, Panayi GS, Janossy G, Poulter LW. An immunohistological analysis of lymphocyte subpopulations and their microenvironment in the synovial membranes of patients with rheumatoid arthritis using monoclonal antibodies. Clin Exp Immunol 1982;49:22-31. 